\title{
A social vaccine for COVID-19
}

The coronavirus disease 2019 (COVID-19) is a highly transmittable and pathogenic viral infection caused by severe acute respiratory syndrome coronavirus 2 (SARS-CoV-2). It emerged from Wuhan, in the Hubei Province of China. The World Health Organization declared a global public health emergency on 30 January 2020 Since then, it has spread to numerous countries worldwide. A number of articles in this issue focus on the pandemic, such as identifying gaps in the implementation of international health regulations in Africa, the use of public health promotion for vulnerable young women and the mental health impact on and response for health workers.

Efforts have been made in past decades to develop vaccines against human coronavirus infections such as Middle East respiratory syndrome (MERS) and severe acute respiratory syndrome (SARS). However, to date, no licensed antiviral treatment or vaccine exists for MERS or SARS. ${ }^{[1]}$ With confirmed SARSCoV-2 cases worldwide surpassing 10 million and continuing to grow, clinicians and scientists are pushing forward with efforts to develop vaccines and treatments to slow the pandemic and lessen the morbidity and mortality associated with the disease. As of 24 June 2020, there are 16 candidate vaccines in clinical evaluation, and 125 in preclinical evaluation. ${ }^{[2]}$ While the world is eagerly waiting for the discovery of a clinical vaccine for SARSCoV-2, we would like to draw your attention to the concept of a 'social vaccine'.

The social vaccine is a concept whose meaning and scope has been evolving over the last three decades. The origin of the concept arose in counselling and psychological studies in 1990 by the California Task Force to Promote Self-esteem. ${ }^{[3,4]}$ A social vaccine is defined as as any measure or set of measures that protects a society against ill being, just as a medical vaccine protects the individual against ill health. ${ }^{[5]}$ It is a metaphor for a series of social and behavioural measures that governments can use to raise public consciousness about unhealthy situations. ${ }^{[6]}$

Subsequently, the term has been used in the field of HIV/AIDS with social communication and behavioural changes, education, ${ }^{[7]}$ social inclusion, income and job security, social security and solidarity, ${ }^{[8]}$ as well as a comprehensive package of preventive education, promotion of contraceptive use and edification of communities. ${ }^{[5,9]}$

When applied to pandemics, the effectiveness of a social vaccine is determined by the extent of dissemination and uptake of accurate information about personal infection risk and methods to reduce the risk. Uganda and Thailand used social and behaviour change communication (SBCC)-based social vaccines effectively during the HIV/AIDS pandemic to bring down the incidence of HIV infection, before the introduction of highly active antiretroviral treatment (HAART). These countries demonstrated the effectiveness of social vaccination to 'flatten the curve' until effective treatments were discovered. ${ }^{[6]}$ The
ABC strategy (Abstinence, Be faithful, use a Condom) and advocacy against stigma and discrimination were successfully adapted in South Africa for managing the HIV/AIDS epidemic. These experiences can be innovatively adapted to create a social vaccine against the current pandemic. In the case of SARS-CoV-2, it would require a process of social and political mobilisation with interventions, applied to populations rather than individuals, aiming at mitigation of risk associated with the structural, social and economic conditions that increase the vulnerability of a population. ${ }^{[10]}$

Social mobilisation would enable a community to collectively develop processes for resistance to unhealthy practices, increasing resilience and fostering advocacy for change. Examples of current practices could include a ' $4 \mathrm{M}$ ' strategy, focusing on:

- managing physical distance in social situations (unless impossible)

- masking (or use of facial coverings) in public (especially where distancing is impossible) by $100 \%$ of people (and 100\% of the time)

- maintaining cleanliness by regular disinfection (washing) of oneself with soap and hand sanitisers, and cleaning one's surroundings

- moral support for affected individuals and families.

Effective and innovative information, education and communication materials and active support from leadership by practising the strategies mentioned above should address the barriers to and facilitators of their implementation. Coercive or punitive methods are invariably counter-productive, as was seen in the case of HIV/AIDS.

It would also require political mobilisation, through investment in: health (scaling up screening and testing); social development (meeting the basic and economic needs of vulnerable sections of the population); economic development (encouraging local production of materials such as personal protective equipment, soap, hand sanitisers and essential medical equipment (such as vital sign monitors)); and innovative social marketing of these issues.

There is still no biomedical vaccine for many diseases of public health importance, such as HIV/AIDS, Chagas disease, Chikungunya, hookworm infection, leishmaniosis, malaria and schistosomiasis. Considering the limited efficacy and uptake of influenza vaccines, vaccines for SARS-CoV-2 may not provide a panacea in the near future. Effective treatments to reduce morbidity and mortality may emerge, but until then, and even afterwards, a social vaccine may assist as an important preventive measure to address widespread fear of infection, stigma, discrimination and violence (towards infected individuals, their families and social groups including healthcare workers). It could also empower communities to nullify conspiracy theories, 
misinformation and the use of unproven remedies. A social vaccine can build societal immunity to the devastating effects of future pandemics by the lessons learned about addressing the root causes of these pandemics.

\section{Deb Basu}

Editor

Debashis.Basu@up.ac.za

\section{Gwendoline Malegwale Ramokgopa}

WHO Collaborating Centre for SDH and HiAP, University of Pretoria Gwendoline.Ramokgopa@up.ac.za

South Afr J Pub Health 2020;4(2):32-33. https://doi.org/10.7196/ SHS.2020.v4.i2.122

1. Dhama K, Sharun K, Tiwari R, et al. COVID-19, an emerging coronavirus infection: Advances and prospects in designing and developing vaccines, immunotherapeutics, and therapeutics. Hum Vaccin Immunother 2020:16(6):1-7. https://doi.org/10.1080\% 2F21645515.2020.1735227
2. World Health Organization. Draft landscape of COVID-19 candidate vaccines. Geneva: WHO, 2020. https://www.who.int/publications/m/item/draft-landscape-of-covid-19candidate-vaccines (accessed 28 June 2020).

3. California State Department of Education. Toward a state of esteem - the final report of the California Task Force to Promote Self-esteem and Personal and Social Responsibility Sacramento: California State Department of Education, 1990. http://www.eric.ed.gov/ PDFS/ED321170.pdf (accessed 28 June 2020).

4. Walz GR. Counselling to enhance self-esteem. ERIC Digest (ED328827). Ericdigests.org 31 January 1991. http://www.ericdigests.org/pre-9219/self.htm (accessed 28 June 2020).

5. Safaei J. Social policy as social vaccine. Soc Med 2014;8(1):672. https://socialmedicine.info/ index.php/socialmedicine/article/view/672 (accessed 28 June 2020).

6. John TJ, Tharyan P. A shot of hope with a game-changing vaccine. The Hindu, 2020 https://www.thehindu.com/opinion/lead/a-shot-of-hope-with-a-game-changingvaccine/article31383184.ece (accessed 28 June 2020)

7. Baker DP Collins JM, Leon J. Risk factor or social vaccine? The historical progression of the role of education in HIV and AIDS infection in sub-Saharan Africa. Prospects 2009:38(4): 467-486. https://doi.org/10.1007/s11125-009-9097-y

8. International Labour Organization. AIDS in the world of work. World of Work Magazine 1999;32:7-11. http://www.lo.org/global/publications/magazinesand-journals/world-ofworkmagazine/issues/ (accessed 28 June 2020)

9. Ministry of Foreign Affairs, Japan. Japan's initiative in the fight against infectious and parasitic diseases on the occasion of the Kyushu-Okinawa G8 Summit ("Okinawa ID (Infectious diseases) Initiative"). Tokyo: Ministry of Foreign Affairs, 2000. http://www.mofa. go.jp/policy/oda/summit/infection (accessed 28 June 2020).

10. Baum F, Narayan R, Sanders D, Patel V, Quizhpe A. Social vaccine to resist and change unhealthy social and economic structures: A useful metaphor for health promotion Health Promot Int 2009:24(4):428-433. https://doi.org/10.1093/heapro/dap026 